\title{
PERBEDAAN PENURUNAN TEKANAN DARAH SISTOLIK LANJUT USIA HIPERTENSI YANG DIBERI JUS TOMAT (Lycopersicum commune) DENGAN KULIT DAN TANPA KULIT
}

\author{
Grace Sabilla Aiska, Aryu Chandra* \\ Program Studi Ilmu Gizi Fakultas Kedokteran Universitas Diponegoro \\ Jl.Dr.Sutomo No.18, Semarang, Telp (024) 8453708, Email : gizifk@ undip.ac.id
}

\begin{abstract}
Background : Untreated hypertension leads to heart failure, renal disease, retinopathy and peripheral vascular disease. The role of lycopene in lowering blood pressure is to prohibit the arterial wall thickening and stiffening by control the smooth muscle tonus of the vessel.

Objective : The aim of this study was to analyze the comparison of hypertensive elderly systolic blood pressure lowering which is given whole and peeled tomato juice (Lycopersicum commune).

Method : This study is a quasi experimental research with pre - post group design. The subjects were 34 hypertensive elderly with systolic blood pressure $120-190 \mathrm{~mm} \mathrm{Hg}$. Subjects were divided into 2 group, i.e treatment group I (whole tomato juice) and treatment group II (peeled tomato juice) use doses $150 \mathrm{~g}$ blanched raw tomatoes, $50 \mathrm{ml}$ water, and $2 \mathrm{~g}$ of sugar for 7 days. Normality test used Shapiro-Wilk. Wilcoxon test were used to analyze difference systolic blood pressure before and after treatment in both groups because of abnormal data. Mann-Whitney test were used to analyze systolic blood pressure lowering difference between 2 groups because of abnormal data.

Result : Treatmen group I has systolic blood pressure mean 144,71 \pm 18,07 mmHg before treatment and 134,71 \pm $17,72 \mathrm{mmHg}$ after treatment therefore its lowering was $10,00 \pm 7,91 \mathrm{mmHg}$ with $\mathrm{p}=0,001$. Treatment group II has systolic blood pressure mean 140,59 $\pm 20,45 \mathrm{mmHg}$ before treatment and 134,71 \pm 15,46 $\mathrm{mmHg}$ after treatment therefore its lowering was 5,88 \pm 7,12 $\mathrm{mmHg}$ with $p=0,008$. Man-Whitney test showed that the lowering between treatment group I and II has $p=0,218$

Conclusion : There was systolic blood pressure lowering before and after treatment in each group, but no significant lowering difference between 2 groups.

Key words : Whole tomato juice; peeled tomato juice; hypertension; elderly
\end{abstract}

\begin{abstract}
ABSTRAK
Latar Belakang : Hipertensi meningkatkan peluang terjadinya penyakit ginjal dan kardiovaskuler serta gangguan sistem saraf dan retinopati. Likopen berperan dalam menurunkan tekanan darah dengan cara mencegah penebalan dan pengerasan dinding arteri dengan mengendalikan tonus otot polos pembuluh darah.

Tujuan : Menganalisis perbedaan penurunan tekanan darah sistolik lanjut usia hipertensi yang diberi jus tomat (Lycopersicum commune) dengan kulit dan tanpa kulit.

Metode : Penelitian ini merupakan penelitian quasi experimental dengan rancangan pre-post grup design. Subyek penelitian ini adalah 34 lanjut usia hipertensi yang memiliki tekanan darah sistolik $120-190 \mathrm{~mm} \mathrm{Hg}$. Subyek dibagi menjadi 2 kelompok yaitu kelompok perlakuan I (jus tomat dengan kulit) dan kelompok perlakuan II (jus tomat tanpa kulit) dengan dosis $150 \mathrm{~g}$ tomat yang diblanch, air $50 \mathrm{ml}$, dan gula $2 \mathrm{~g}$ selama 7 hari. Uji normalitas menggunakan uji Saphiro-Wilk. Uji Wilcoxon untuk melihat perbedaan tekanan darah sistolik sebelum dan sesudah perlakuan pada kedua kelompok karena distribusi data tidak normal. Data perbedaan penurunan tekanan darah sistolik diuji dengan Mann-Whitney karena distribusi data tidak normal.

Hasil : Pada kelompok perlakuan I rata-rata tekanan darah sistolik sebelum perlakuan 144,71 $\pm 18,07 \mathrm{mmHg}$ menjadi $134,71 \pm 17,72 \mathrm{mmHg}$ setelah perlakuan sehingga terjadi penurunan tekanan darah sistolik sebesar 10,00 \pm 7,91 mmHg dengan $p=0,001$. Sedangkan pada kelompok perlakuan II rata-rata tekanan darah sistolik sebelum perlakuan 140,59 $\pm 20,45 \mathrm{mmHg}$ menjadi 134,71 \pm 15,46 $\mathrm{mmHg}$ setelah perlakuan sehingga terjadi penurunan tekanan darah sistolik sebesar 5,88 \pm 7,12 mmHg dengan p=0,008. Uji Man-Whitney menunjukkan penurunan tekanan darah sistolik kedua kelompok memiliki $p=0,218$.

Kesimpulan : Terdapat penurunan tekanan darah sistolik sebelum dan sesudah perlakuan pada masing-masing kelompok ( $p<0.05)$, tetapi antara kelompok I dan II tidak terdapat perbedaan penurunan tekanan darah sistolik yang bermakna $(p>0,05)$.
\end{abstract}

Kata kunci : Jus tomat dengan kulit; jus tomat tanpa kulit; hipertensi; lanjut usia

PENDAHULUAN

${ }^{*}$ Penulis Penanggungjawab
Hipertensi merupakan kondisi tekanan darah tinggi pada pembuluh darah arteri yang 
berlangsung secara terus-menerus dalam jangka waktu lama. Hipertensi meningkatkan peluang terjadinya penyakit ginjal dan kardiovaskuler serta gangguan sistem saraf dan retinopati. Hipertensi dipengaruhi oleh gaya hidup seperti aktivitas fisik kurang, kebiasaan merokok, konsumsi alkohol berlebih, serta asupan sodium tinggi sedangkan asupan sayur dan buah rendah. ${ }^{1}$

Menurut hasil Riset Kesehatan Dasar (Riskesdas) tahun 2007 penduduk Jawa Tengah berusia lebih dari 17 tahun yang menderita hipertensi sebesar $34,9 \%$ sedangkan penduduk Kota Semarang pada golongan usia tersebut yang menderita hipertensi sebesar 40,8\%. Jawa Tengah merupakan provinsi dengan persentase penduduk lansia (lanjut usia) terbesar ke tiga (10,34\%) setelah Yogyakarta dan Jawa Timur. ${ }^{3}$

Pemilihan makanan yang bergizi bagi lansia diperlukan untuk menjaga kesehatan dan mencegah penyakit atau komplikasi dari penyakit yang sudah diderita lansia. Zat gizi yang dapat menunjang kesehatan dan mencegah hipertensi diantaranya adalah karotenoid, kalium, asam lemak omega 3, dan serat. ${ }^{4}$ Salah satu karotenoid yang terdapat dalam makanan adalah likopen. Aktivitas antioksidan likopen dua kali lebih baik dari $\beta$ karoten. Bahan makanan yang merupakan sumber likopen salah satunya adalah tomat. ${ }^{5}$ Terdapat 9,27 mg likopen dalam $100 \mathrm{~g}$ tomat mentah. ${ }^{6}$

Selain likopen, tomat juga menjadi sumber kalium, asam folat, vitamin A, C, E, dan serat yang dapat membantu menurunkan tekanan darah. Tomat matang juga mengandung zat gizi bioaktif seperti tocopherols, phenolics, glycoalkaloids, flavonoids. ${ }^{6}$ Penelitian di Selandia Baru menunjukkan bahwa kulit dan biji tomat memberikan kontribusi $53 \%$ total phenolics, 52\% total flavonoids, $48 \%$ total likopen, dan $43 \%$ total asam askorbat. ${ }^{8}$

Lansia termasuk kelompok rawan gizi karena lansia telah mengalami proses penuaan yang menyebabkan penurunan fungsi fisiologis. Pemenuhan kebutuhan gizi lansia dapat diperoleh dengan mengonsumsi sayur dan buah yang kaya antioksidan. Tomat merupakan bahan makanan yang murah, mudah didapat, mudah diolah, dan lunak, sehingga lansia mudah mengkonsumsinya.

Beberapa olahan tomat yang menghilangkan kulitnya antara lain sirup, puree, saos dan tomat kalengan. Rerata kandungan likopen dalam $100 \mathrm{~g}$ tomat utuh $10,7 \mathrm{mg}$, sedangkan rerata kandungan likopen dalam $100 \mathrm{~g}$ tomat tanpa kulit adalah 2,1 mg. Pengupasan kulit menyebabkan tomat kehilangan likopen sebesar
$71 \%$. ${ }^{9}$ Tomat yang mengalami proses pemasakan mengubah bentuk all-trans lycopene menjadi cislycopene isomers yang lebih larut dalam misel asam basa sehingga lebih mudah dicerna. ${ }^{10}$

Tingginya angka kejadian hipertensi dan banyaknya penelitian yang mendukung tentang tomat dalam menurunkan tekanan darah menjadi alasan peneliti ingin mengkaji lebih jauh mengenai pengaruh pemberian jus tomat dengan kulit dan tanpa kulit terhadap penurunan tekanan darah sistolik lansia.

\section{METODE}

Penelitian ini adalah penelitian quasi experiment dengan rancangan pre-post group design yang menggunakan manusia sebagai subjek penelitian. Variabel bebas dalam penelitian adalah pemberian jus tomat dengan kulit dan tanpa kulit. Jus tomat dengan kulit perhari terbuat dari tomat merah utuh $150 \mathrm{~g}$ yang diblanching satu menit lalu ditambahkan air $50 \mathrm{ml}$ dan gula $2 \mathrm{~g}$ sedangkan jus tomat tanpa kulit dibuat dengan dosis yang sama dari tomat merah kupas. Pemberian jus tomat dilakukan selama 7 hari dengan dosis tersebut perhari. Variabel terikat pada penelitian ini adalah penurunan tekanan darah sistolik pada kedua kelompok perlakuan.

Subjek penelitian adalah lansia yang dibina di panti rehabilitasi atau panti wreda Kota Semarang diambil dengan menggunakan metode consecutive sampling yang memenuhi kriteria antara lain berusia > 60 tahun dan memiliki tekanan darah sistolik $\geq 120 \mathrm{mmHg}$ dan memiliki riwayat hipertensi minimal setahun terakhir. Kriteria eksklusi pada subjek penelitan yaitu mengkonsumsi obat dan suplemen antihipertensi secara rutin, tidak kooperatif, mengundurkan diri saat penelitian berlangsung, dan meninggal dunia saat penelitian berlangsung. Lansia yang bersedia menjadi subjek penelitian diminta menandatangani informed consent. Selanjutnya dilakukan pengukuran tekanan darah untuk mengetahui apakah tekanan darah sistolik subjek memenuhi kriteria inklusi.

Subjek yang memenuhi seluruh kriteria inklusi dan dinyatakan sebagai sampel penelitian kemudian dibagi menjadi dua kelompok secara acak. Kelompok I merupakan kelompok yang diberi jus tomat dengan kulit, sedangkan kelompok II diberi jus tomat tanpa kulit. Setelah sampel penelitian diberi jus tomat sesuai kelompok perlakuan, dilakukan pengukuran tekanan darah sistolik kembali. Pemilihan sampel penelitian terhadap kelompok lansia dilakukan di dua panti 
wreda Kota Semarang. Sebanyak 21 lansia di panti wreda Singosari masuk ke dalam kriteria subjek penelitian sedangkan di panti wreda Pucang Gading sebanyak 17 lansia. Pembagian subjek penelitian ke dalam dua kelompok perlakuan dilakukan pada setiap panti wreda.

Data yang terkumpul merupakan data primer berupa data umum dan kondisi kesehatan berdasarkan catatan di panti dan wawancara dengan subjek serta tekanan darah sistolik dari hasil pengukuran yang dilakukan oleh perawat.

\section{HASIL PENELITIAN}

Karakteristik subjek sebelum perlakuan

Pada saat penelitian terdapat masingmasing dua subjek dari kelompok I dan kelompok II drop out sehingga jumlah akhir subjek adalah 34 lansia, terdiri dari 17 lansia kelompok perlakuan I dan 17 lansia pada kelompok perlakuan II. Gambaran usia dan jenis kelamin subjek disajikan dalam tabel 1.

Tabel 1. Karakteristik Usia dan Jenis Kelamin Subjek

\begin{tabular}{lcccc}
\hline \multirow{2}{*}{ Jenis Pengukuran } & \multicolumn{2}{c}{ Kelompok I } & \multicolumn{2}{c}{ Kelompok II } \\
\cline { 2 - 5 } & $\mathrm{n}$ & $\%$ & $\mathrm{n}$ & $\%$ \\
\hline Usia & 5 & 29,40 & 5 & 29,40 \\
61-70tahun & 9 & 52,90 & 9 & 52,90 \\
$71-80$ tahun & 3 & 17,60 & 3 & 17,60 \\
81-90 tahun & & & & \\
Jenis Kelamin & 4 & 23,50 & 4 & 23,50 \\
Laki-laki & 13 & 76,50 & 13 & 76,50 \\
Perempuan & & & \\
\hline
\end{tabular}

Tabel 1 menunjukkan jumlah subjek dalam setiap rentang usia pada kelompok I sama dengan kelompok II. Subjek kelompok I maupun kelompok II paling banyak pada rentang usia 7180 tahun $(52,90 \%)$. Jumlah subjek laki-laki pada kedua kelompok perlakuan juga sama, demikian pula dengan jumlah subjek perempuan pada kedua kelompok perlakuan. Tekanan darah sistolik sebelum perlakuan pada kelompok I rata-rata $144,71 \mathrm{mmHg}$ sedangkan kelompok II 140,59 mmHg. Hasil uji Mann-Whitney tidak terdapat perbedaan tekanan darah sistolik sebelum perlakuan pada kelompok I dan kelompok II $(\mathrm{p}>0,05)$.

Perbedaan penurunan tekanan darah sistolik lansia hipertensi yang diberi jus tomat dengan kulit dan tanpa kulit
Pada kelompok perlakuan I rata-rata tekanan darah sistolik sebelum perlakuan 144,71 \pm $18,07 \mathrm{mmHg}$ menjadi $134,71 \pm 17,72 \mathrm{mmHg}$ setelah perlakuan sehingga terjadi penurunan tekanan darah sistolik sebesar 10,00 \pm 7,91 $\mathrm{mmHg}$ dengan $\mathrm{p}=0,001$. Sedangkan pada kelompok perlakuan II rata-rata tekanan darah sistolik sebelum perlakuan $140,59 \pm 20,45 \mathrm{mmHg}$ menjadi $134,71 \pm 15,46 \mathrm{mmHg}$ setelah perlakuan sehingga terjadi penurunan tekanan darah sistolik sebesar $5,88 \pm 7,12 \mathrm{mmHg}$ dengan $\mathrm{p}=0,008$. Uji ManWhitney menunjukkan penurunan tekanan darah sistolik kedua kelompok memiliki $\mathrm{p}=0,218$. Perbedaan tekanan darah sistolik sebelum dan setelah perlakuan pada kedua kelompok perlakuan disajikan pada tabel 2 .

Tabel 2. Tekanan Darah Sitolik (TDS) Sebelum dan Sesudah Perlakuan

\begin{tabular}{llll}
\hline \multirow{2}{*}{ Jenis pengukuran } & \multicolumn{1}{c}{ Kelompok 1 $(\mathrm{n}=17)$} & \multicolumn{1}{c}{ Kelompok 2 $(\mathrm{n}=17)$} & $\mathrm{p}$ \\
\cline { 2 - 3 } & Mean \pm SD & Mean \pm SD & $0,413^{\mathbf{b}}$ \\
\hline TDS sebelum $(\mathrm{mg} \mathrm{Hg})$ & $144,71 \pm 18,07$ & $140,59 \pm 20,45$ & \\
TDS sesudah $(\mathrm{mg} \mathrm{Hg})$ & $134,71 \pm 17,72$ & $134,71 \pm 15,46$ & \\
$\Delta$ TDS & $-10,00 \pm 7,91$ & $-5,88 \pm 7,12$ & $0,218^{\mathbf{b}}$ \\
$\mathrm{p}$ & $0,001^{\mathbf{a}}$ & $0,008^{\mathbf{a}}$ & \\
\hline
\end{tabular}

\section{${ }^{\mathrm{a} u j i}$ Wilcoxon, ${ }^{\mathrm{b}} \mathrm{uji}$ Mann-Whitney}

Tabel 2 menunjukkan penurunan tekanan darah sistolik sebelum dan sesudah perlakuan pada kedua kelompok memiliki perbedaan $(\mathrm{p}<0.05)$, tetapi tidak ada perbedaan penurunan tekanan darah sistolik yang bermakna antara kelompok I dengan kelompok II ( $p>0,05)$. 


\section{PEMBAHASAN}

Hipertensi merupakan suatu sindrom metabolik yang berkaitan dengan penyakit kardiovaskuler pada lansia. Hipertensi menjadi indikator paling kuat dan paling sering digunakan untuk mengidentifikasi terjadinya infark miokard, gagal jantung, stroke, dan gagal ginjal. Hipertensi dipengaruhi oleh gaya hidup seperti aktivitas fisik kurang, kebiasaan merokok, konsumsi alkohol berlebih, serta asupan sodium tinggi sedangkan asupan sayur dan buah rendah. ${ }^{1}$

Karakteristik subjek pada penelitian ini adalah lansia hipertensi dengan rentang usia 61 90 tahun dengan distribusi rentang usia pada kedua kelompok perlakuan sama. Distribusi jenis kelamin kedua kelompok juga sama sehingga usia dan jenis kelamin tidak mempengaruhi hasil penelitian. Tidak terdapat perbedaan yang bermakna antara tekanan darah sistolik sebelum perlakuan pada kelompok perlakuan I dan kelompok perlakuan II. Hal ini juga dapat meminimalkan pengaruh perbedaan tekanan darah sistolik sebelum perlakuan terhadap hasil penelitian.

Selama penelitian terdapat 2 subjek (1 subjek pada tiap kelompok perlakuan) di panti wreda A dan 2 subjek di panti wreda B (masingmasing 1 subjek juga pada kelompok I dan II) yang di drop out. Drop Out dilakukan karena subjek tidak bersedia diukur tekanan darahnya, tekanan darah sistolik menjadi $110 \mathrm{mmHg}$, serta tidak kooperatif dalam mengkonsumsi jus tomat yang diberikan. Alasan drop out yang terakhir berkaitan dengan upaya peneliti dalam meminimalkan perbedaan dosis jus tomat yang dikonsumsi subjek sehingga tidak mempengaruhi hasil penelitian.

Pemberian jus tomat dengan kulit dan jus tomat tanpa kulit masing-masing dapat menurunkan tekanan darah sistolik. Hasil uji statistik menunjukkan ada perbedaan antara tekanan darah sistolik sebelum dengan sesudah perlakuan pada masing-masing kelompok $(\mathrm{p}<0.05)$. Tekanan darah sistolik pada kelompok I mengalami penurunan dengan rata-rata $-10,00$ $\mathrm{mmHg}$ setelah perlakuan. Pada kelompok II juga mengalami penurunan tekanan darah sistolik dengan rata-rata $-5,88 \mathrm{mmHg}$. Penurunan tekanan darah sistolik ini disebabkan salah satunya karena likopen yang ada dalam jus tomat.

Likopen merupakan senyawa fitokimia yang bermanfaat bagi kesehatan. Likopen termasuk salah satu karotenoid larut lemak yang disintesis oleh beberapa mikroorganisme dan tanaman tapi tidak dapat disintesis oleh hewan dan manusia. Bentuk likopen di alam berupa all trans isomers sehingga stabil dari oksidasi, pemanasan, dan photodegradation. Likopen mudah diserap dalam bentuk tomat yang sudah diolah dibanding tomat mentah, karena pada tomat yang diolah likopen berubah bentuk menjadi bentuk cis-isomer. ${ }^{11}$

Berdasarkan hasil penelitian tahun 2004 pada pasien hipertensi rawat jalan di Bandung, penurunan tekanan darah sistolik $10,28 \mathrm{mmHg}$ dan diastolik 3,49 $\mathrm{mmHg}$ dengan pemberian jus tomat yang terbuat dari $150 \mathrm{~g}$ buah tomat dan $5 \mathrm{~g}$ gula pasir selama 2 hari berturut-turut. ${ }^{12}$ Menurut penelitian di Semarang tahun 2012 pemberian jus tomat dengan komposisi tersebut selama 7 hari berturut-turut dapat menurunkan tekanan darah sistolik dan diastolik secara signifikan pada wanita postmenopause hipertensi. ${ }^{13}$

Pemberian jus tomat dengan perbedaan perlakuan pada kulit (utuh dan dikupas) dikarenakan adanya kandungan likopen pada kulit tomat. Konsentrasi likopen dalam serum manusia cenderung lebih tinggi daripada semua karotenoid lainnya. Likopen memberikan efek antiinflamasi melalui tindakan sebagai antioksidan yang dapat mengurangi kerusakan sel. Likopen juga mencegah penebalan dan pengerasan dinding arteri dengan mengendalikan tonus otot polos pembuluh darah. ${ }^{14}$

Hasil uji statistik menunjukkan tidak ada perbedaan penurunan tekanan darah sistolik yang bermakna antara kelompok I dengan kelompok II ( $>0,05)$. Penurunan tekanan darah sistolik kedua kelompok tidak berbeda karena selain likopen, tomat juga mengandung kalium, vitamin $\mathrm{C}$, dan vitamin A yang berperan dalam menurunkan tekanan darah sehingga jus tomat tanpa kulit tetap dapat menurunkan tekanan darah sistolik lansia hipertensi. Terdapat $222 \mathrm{mg}$ kalium, 19,1 mg vitamin $\mathrm{C}$, dan $623 \mathrm{IU}$ vitamin A dalam $100 \mathrm{~g}$ tomat segar. ${ }^{14}$

Asupan kalium juga berhubungan dengan perubahan tekanan darah. Tekanan darah sistolik berkurang $0,9 \mathrm{mmHg}$ dan diastolik berkurang 0,8 mmHg jika asupan kalium 1000 mg perhari. ${ }^{4}$ Deplesi kalium berkaitan dengan penurunan ekskresi sodium, aktivitas renin plasma, konsentrasi plasma aldosteron, serta peningkatan tekanan darah sistolik $7 \mathrm{mmHg}$ dan diastolik 6 $\mathrm{mmHg}$. Efek antihipertensif kalium dengan cara: (1) natriuresis, yaitu menghambat reabsorpsi natrium di tubulus renal proksimal dan menekan sekresi renin, (2) menormalkan kadar substansi digitalis like plasma, (3) meningkatkan volume ekskresi urin, (4) relaksasi otot halus melalui produksi oksida nitrat, (5) menekan pembentukan 
radikal bebas, (6) melindungi pembuluh darah dari luka akibat hipertensi. ${ }^{4}$

\section{SIMPULAN}

Terdapat penurunan tekanan darah sistolik pada lansia yang diberi jus tomat dengan kulit maupun tanpa kulit, tetapi tidak ada perbedaan penurunan tekanan darah sistolik antara kedua kelompok perlakuan tersebut.

\section{SARAN}

Perlu dilakukan uji kandungan likopen dalam jus tomat dengan kulit dan jus tomat tanpa kulit terlebih dahulu sebelum digunakan penelitian. Penelitian selanjutnya membutuhkan kelompok kontrol dan analisis konsumsi makan subjek lebih mendalam.

\section{DAFTAR PUSTAKA}

1. Mahan L. Kathleen, Escott - Stump Sylvia, Raymond Janice L. Krause's: Food and the Nutrition Care Process. $13^{\text {th }}$ Edition. Philadelphia: Saunders; 2012. p.758-769

2. Riset Kesehatan Dasar (Riskesdas) 2007. Jakarta: Departemen Kesehatan Republik Indonesia. 2008

3. Survey Sosial Ekonomi Nasional (Susenas) 2011. Jakarta: Badan Pusat Statistik (BPS). 2013. Available from : URL: HYPERLINK: http://www.bps.go.id/hasil_publikasi/stat_lansia_20 $\underline{11}$

4. Ha Nguyen et al. A Review of Nutritional Factors in Hypertension Management. International Journal of Hypertension 2013; 698940: 3-7

5. Yaling Yang et al. Effects of Some Common Food Constituents on Cardiovascular Disease. ISRN Cardiology 2011; 397136

6. Engelmann NJ, Clinton SK, Erdman-Jr JW. Nutritional Aspect of Phytoene and Phytofluene, Carotenoid Precussors to Lycopene. Adv. Nutr 2011; 2: 51-61

7. Canene-Adams K, Campbell JK, Zaripheh S, Jeffery $\mathrm{EH}$, Erdman JW Jr. The tomato as a functional food. J Nutr. 2005; 135: 1226-30

8. Toor RK, Savage GP. Antioxidant activity in different fractions of tomatoes. Food Res Int 2005; 38(5): 487-494

9. Vinha AF, Alves RC, Barreira SVP, Castro Ana, Costa ASG, Oliveira MBPP. Effect of Peel and Seed Removal on the Nutritional Value and Antioxidant Activity of Tomato (Lycopersicon esculentum L.) Fruits. LWT-Food Science and Technology 2013; 55: 197-202

10. Ahuja KDK, Pittaway JL, Ball MJ. Effect of olive oil and tomato lycopene combination on serum lycopene, lipid profile, and lipid oxidation 2006. J.Nutr;22:259-265
11. Rao AV, Rao LG. Carotenoids and Human Health. Pharmacologycal Research 2007; 55: 207-216

12. Gunawan I.Z, Praminanto G, Rahayu D.Y. Pengaruh Pemberian Jus Belimbing dan Jus Tomat terhadap Perubahan Tekanan Darah Sistolik dan Diastolik pada Penderita Hipertensi di Puskesmas Taragog dan RS Al Islam Bandung. Bandung: Asosiasi Dietisien Indonesia; 2005. hal.405-11

13. Aryati Puji Lestari, Hesti Murwani Rahayuningsih. Pengaruh Pemberian Jus Tomat (Lycopersicum Commune) terhadap Tekanan Darah Wanita Postmenopause Hipertensif. Journal of Nutrition College 2012; 1(1): 26-37

14. Sari Intan Kailaku, Kun Tanti Dewandari, Sunarmani. Potensi Likopen dalam Tomat untuk Kesehatan. Balai Besar Penelitian dan Pengembangan Pascapanen Pertanian: Buletin Teknologi Pascapanen Pertanian. 2007; Vol. 3 